\title{
An Historical Perspective on the Attorney-Client Privilege
}

\author{
Geoffrey C. Hazard, Jr. $\dagger$
}

I am to break with thee some affairs

That touch me near, wherein thou must be secret.

The Two Gentlemen of Verona,

Act iii, sc. 1.*

In his professional life David was mostly concerned with the procedure of litigation, particularly in the adversary system. He believed deeply in the adversary system as an expression of humane concerns, for lie saw it as recognizing both the fallibility and the dignity of man. $\mathrm{He}$ also believed deeply in the idea of evidentiary privilege-tliat there are some things, indeed many things, im life that should not be open to public inspection, even for "good cause." It is therefore especially satisfying to say something in his memory about the attorney-client privilege, for that privilege involves an imtersection of the mechanisn of adjudication with the law of privacy.

The attorney-client privilege may well be the pivotal element of the modern American lawyer's professional functions. It is considered indispensable to the lawyer's function as advocate on the theory that the advocate can adequately prepare a case only if the client is free to disclose everything, bad as well as good. The privilege is also considered necessary to the lawyer's function as confidential counselor in law on the similar theory that the legal counselor can properly advise the client what to do only if the client is free to make full disclosure.

There has always been some anxiety about the privilege, as there is about all privileges. As a matter of common sense it is unlikely that a client would wish to withhold from his lawyer information that puts him or his cause in a favorable light. Of course, it is possible that a particular client on a particular occasion may be concerned with the privilege as a matter of primciple-wishing to avoid even the most flat-

$\dagger$ John A. Garver Professor of Law, Yale University. B.A. 1953, Swarthmore College; LL.B. 1954, Colunbia University. The author is Consultant to the American Bar Association Commission to Evaluate Profcssional Standards. The views herein are those of the author alone.

* I am not well acquainted with Shakespeare, but David was. In memnory of him I presume to tender apt quotation. 
tering revelations of his affairs and his self. Yet assuming there are such instances, it seems fair to say they are greatly outnumbered by those in which the principle of privacy is invoked to conceal legally dubious or dirty business. And when dubious or dirty business has been done, most likely someone has suffered as a result. In the nature of things, then, the attorney-chent privilege has its victims.

In the procedural contexts in which the attorney-chent privilege is invoked, the identity of the victim is usually not difficult to discern. It is the party seeking disclosure of the confidence. Hence, the coinmon sense estimate of situations involving the attorney-client privilege is that the lawyer, though an "officer of the court," is allowed to conceal wrong-doing by the client in the face of a specific demand for its disclosure by the very person suffering the wrong. ${ }^{1}$ There may be a sufficient justification for the privilege; indeed the verdict of our legal history is to that effect. But no argument of justification should ignore the fact that the attorney-client privilege, as far as it goes, is not only a principle of privacy, but also a device for cover-ups. That, of course, is what inakes contemplation of it both interesting and troublimg.

\section{I}

\section{The Present Scene}

In present-day law, the issue concerning the attorney-chent privilege is not whether it should exist, but precisely what its terms should be. There is no responsible opimion suggesting that the privilege be completely abolished. Total abohtion would mean that an accused in a criminal case could not explain his version of the matter to his lawyer without its being transimitted to the prosecution. Defense counsel would become a mediuin of confession, a result that would substantially impair both the accused's right to counsel and the privilege agamst self-incrimination. Hence, it is common ground that the privilege ought to apply at least to communications by an accused criminal ${ }^{2}$ to his counsel, ${ }^{3}$ in contemplation of defense of a pendimg or imminently threatened ${ }^{4}$ prosecution, ${ }^{5}$ concerning a completed crime. ${ }^{6}$ Beyond this

1. It may be thought that this is not true when the privilege is applied to communications between a criminal defendant and his counsel. In such a situation, so it might be said, there is no immediate victim because the state is the opposing party. If one bears in mind the victims of homicide, rape, robbery, and embezzlement, whose oppression is the occasion of criminal prosecution, however, such an argument carries little weight.

2. Whether it should also apply to communications to the accused's counsel froin other persons, such as the accused's spouse, is more problematic.

3. Another problem is whether it should apply to communications with aides of counsel, such as a clerk. See, e.g., Barnes v. Harris, 61 Mass. (7 Cush.) 576 (1851).

4. A pending prosecution ought plainly to be withim the privilege, or the privilege is pointless. An "imminently threatened" prosecution can be assimilated to one that is pending by simply denying legal significance to the movement of a file from the police to prosecutor or the court system. But if the crime is as yet wholly undiscovered, or prosecution is only a future contingency, 
there is controversy as to the proper scope of the privilege, although superficially the authorities are im substantial agreement.

One convenient statement of the rule of privilege appears in Rule 26 of the Uniform Rules of Evidence. ${ }^{7}$ In this formulation, the privilege attaches to "communications . . . between lawyer and his chent in the course of that relationship and in professional confidence . . . unless the legal service was sought or obtamed . . . to commit or plan to commit a crime or a tort . . ." The rule apphes to consultations concerning civil as well as criminal hitigation, to plaintiffs as well as defendants, to consultations in which the client seeks advice only and not simply assistance in litigation, and to communications whose aim is assistance other than in litigation, sucl as drafting legal documents. And so the privilege is generally understood.

Yet upon closer reading, the scope of the rule is not so plain. This becomes evident when the rule is applied to situations (aside from the criminal defendant's communication to an attorney) where its exclusionary effect is really important. These are situations in which the client is doing or planning to do something that is very bad, such as committing a crime or destroying evidence, or where the client wants the lawyer to do something very bad, such as suborning perjury or aiding in fraud. ${ }^{9}$ In such circumstances, it is arguable that the privilege,

the situation is again problematic. Consider, for example, what counsel should do if asked by a client what ought to be done with old business records that might reveal evidence of crime. Compare Shapiro v. United States, 335 U.S. 1 (1948) (busmess records), with In re Ryder, 263 F. Supp. 360 (E.D. Va. 1967) (money taken in bank robbery).

5. A "prosecution" is a proceeding for punishment of a crime. Whether the privilege should apply in other actions for a penalty, such as a suit for punitive redress by a private party, is also problematic. The problem is comparable to that of defining the limits of the privilege agaimst self-mcrimination. See C. MCCormick, Evidence $\$ 121$ (2d ed. 1972).

6. Consultation coucerning an intended crime was held outside the privilege at least a century ago, see The Queen v. Cox \& Railton, 14 Q.B.D. 153 (1884), and (depending on how one reads cases) perhaps two ceuturies ago. See Annesley v. Anglesea, 17 How. St. Trials 1139 (1743) (also captioned Craig v. Anglesea, see note 53 infra). The most difficult problem is that arising when the clieut is engaged in a course of criminal conduct (e.g., antitrust violations, building code violatious) that contimues into the present. The conduct becomes protected by the privilege as a coinpleted crime only when it is wholly terminated, but the termination itself may be the subject of the legal consultation.

7. Uniform Rule of Evidence 26. See also ALI Model Code of Evidence rule 212 (1942); Proposed Federal Rules of Evidence rule 503, 51 F.R.D. 315 (1971).

8. There are other exceptious and qualifications that need not detain us. See generally $8 \mathrm{~J}$. Wigmore, Evidence $\$ 2290$ (3d ed. 1940); C. MCCormick, supra note 5, ch. 10.

In some jurisdictions the exception coucerning civil wrongs is defined in terms of "fraud" rather than "tort." This can nuake a difference. See Nowell v. Superior Court, 223 Cal. App. 2d 652, 36 Cal. Rptr. 21 (1963).

9. This is not to say that the attorney-client privilege has no significance in less morally questionable transactious. Of course it is important that a person be able to make a will without having its coutents revealed; it is important for a taxpayer to have private guidance on the tax classification of a transaction whose character for that purpose is ambiguous; it is important for a litigant to be able to review his testimony in confidence prior to beimg subjected to cross-examination, etc. But if it could be assumed that all such transactions were wholly innocuous from a legal 
by its own terms, is not apphicable. That is, if the client has in mind anything but a "legitimate" purpose in consultimg a lawyer, it might be said that communications between them are neither "in the course of" the attorney-client relationship nor in "professional" confidence. ${ }^{10}$ Furthermore, if the consultation is manifestly in aid of proposed conduct that would be a crime or a tort, it is excepted from the privilege by the express terms of the rule. And it inay not be far-fetched to say that it is tortious to inake any use of legal process for a purpose other than a "legitimate" one. ${ }^{11}$

The scope of the attorney-chent privilege in these borderline areas has never been well defined in the cases, ${ }^{12}$ as will be shown. Of course, borders in law can never be inarked with great precision. But the present confusion is coinpounded by the fact that the bar has taken a quite different approach to attorney-chent confidentiahty in its rules of professional ethics.

The law of attorney-client privilege is the product of judicial decisions, augmented by statutes that usually incorporate the decisional law. ${ }^{13}$ This will be called the "privilege rule." The rules of professional ethics, on the other hand, einanate from the legislative process of the legal profession itself. For over a half century, the central legislative source in the legal profession has been the American Bar Association, acting through its House of Delegates. The A.B.A. has undertaken to state rules of professional ethics that it hopes will be adopted by the states through their own bar associations or courts. By this process of adoption, and perhaps simply through recognition of the rules within the profession at large, the bar seeks to establish prevailing norms governing the responsibilities of the attorney in the attorneyclient relationship, including the responsibility to inaintain confidentiahty. The rules promulgated by the bar association therefore have con-

point of view, the privilege would be a mere nicety-valued, perhaps, in a world where personal affairs are all too often open to scrutiny, but not a rule that would engage intense legal debate. Moreover, if all transactions to which the rule apphed were innocuous, the privilege could be given substantial effect simply by requiring that any hearing in which disclosure was made be closed to the public, or that claims of privilege be determined in a hearing in camera.

10. See text accounpanying notes 116-19 infra.

11. See California Motor Transport Co. v. Trucking Unlimited, 404 U.S. 508 (1972).

12. Among the difficulties are whether the lawyer is consulted in his capacity as a professional in law, see, e.g., Banks v. United States, 204 F.2d 666 (8th Cir. 1953), cert. denied, 350 U.S. 986 (1956); whether the lawyer gained knowledge of the matter in question by a "communication," see, e.g., Hawlcy v. Hawley, 114 F.2d 745 (D.C. cir. 1940); under what circumstances it can be said that the client's purpose was a crime, see Annot., 16 A.L.R. 3d 1029 (1967), or a tort, see Annot., 2 A.L.R. 3d 861 (1965), and particularly the problem of a client who imtends to commit perjury, see Wolfram, Client Perjury, 50 So. CAL. L. Rev. 809 (1977); Annot., 64 A.L.R. 3d 385 (1975); and whether it makes a difference that the lawyer is asked to prepare a legal document essential to the transactions in question, see Annot., 55 A.L.R. 3d 1322 (1974).

13. See, e.g., CAL. Evid. CodE $\S 954$ (West Supp. 1978). 
siderable significance ${ }^{14}$ in defining the terms and conditions under which a client's communications to his attorney are to be kept confidential. ${ }^{15}$ The bar's rule as to the proper scope of confidentiality, which will be called the "confidence rule," is, perhaps not surprisingly, more expansive that the rule of attorney-client privilege developed by the courts.

The A.B.A. Canons of Ethics represented the official position of the bar on matters of ethics until 1969, and included two provisions on the subject of confidentiality, canon 37 and canon 41 . Canon 37 provided:

The announced intention of a client to comnnit a crime is not included within the confidences the [lawyer] is bound to respect. He may properly make such disclosures as may be necessary to prevent the act or protect those against whoin it is threatened.

It will be observed that this exception to the confidence rule is narrower than the comparable exception to the attorney-client privilege. It refers to an "announced" intention to commit a crime; the privilege rule requires no such announcement. The difference is thus that under the privilege rule, an attorney who can infer that the client has a criminal purpose in mind has no privilege to keep that purpose a secret, while under the canon's confidence rule the attorney must respect the client's confidences unless explicitly told of such a purpose. Moreover, the canon refers only to crimes, while the privilege rule exempts communications relating a conteinplated torts as well.

Canon 41, the other limitation on confidence in effect until 1969, provided:

When a lawyer discovers that some fraud or deception has been practised, which has unjustly imposed upon the court or a party, he should endeavor to rectify it; at first by advising his client, and if his client refuses to forego the advantage thus unjustly gained, he should promptly inform the injured person or his counsel, so that they may take appropriate steps.

There is a peculiar discrepancy in the temporal dinnension of this canon as conipared with the privilege rule. The exception in the privilege rule

14. The legal status of rules of ethics promulgated by a bar association is a matter of some intricacy. Sometimes such rules, upon adoption by the courts, become in effect legislation, see, e.g., Slater v. Rimar, Inc., $462 \mathrm{~Pa} .138,338 \mathrm{~A} .2 \mathrm{~d} 584$ (1975), and as such are authoritative subject only to constitutional restramts. See, e.g., Chicago Council of Lawyers v. Bauer, 522 F.2d 242 (7th Cir. 1975), cert. denied, 427 U.S. 912 (1976) (rule adopted by fedcral court partially invahd under the first amendment). But cf. In re Hearings Concerning Canon 35, 132 Colo. 591,296 P.2d 465 (1956), holding that bar association rules which have been adopted by the courts are merely guidelines. On the other hand, bar association rules have been apphed as a basis of attorney discipline even though not adopted as rules of court. See, e.g., Hawk v. Superior Court, $42 \mathrm{Cal}$. App. 3d 108, 116 Cal. Rptr. 713 (1974), cert. denied, 421 U.S. 1012 (1975).

15. On the difference between the concept of "privileged" communications between client and attorney and "confidential" communications between client and attorney, see text following note 26 infra. 
refers to legal assistance "to commit or to plan to commit" a fraud, whích plainly indicates future conduct; the exception under the privilege rule also apphies to a past transaction if it appears that the lawyer's services were einployed therein for the purpose of committing a wrong. In contrast, canon 41 has a wider provision for secrecy in that it refers only to past events. ${ }^{16}$ Canon 41 further limits the exception to the confidence rule by referring only to "fraud or deception," while the privilege exception refers to intentional torts generally.

The Canons of Ethics have since been supplanted through a complex of bar legislation whose total import is not entirely clear. The principal text currently in effect is the Code of Professional Responsibility, initially adopted in 1969 and subsequently anended. The Code's confidence rule requires generally that "A lawyer shall not knowingly . . . reveal a confidence or secret of a client." 17 As originally drafted, the Code provided that a lawyer was permitted, but not required, to reveal "the intention of his client to coinmit a crime and the information necessary to prevent the crime." 18 But it made no reference to disclosing fraud by the chent, which had been covered by old canon 41. The draft was therefore amended before the Code was adopted in 1969. The placeinent and terms of the amendment were such, however, that its ineaning was not wholly clear.

The provision concerning fraud appeared in canon 7 of the 1969 Code, providing that "A Lawyer Should Represent a Chent Zealously Within the Bounds of the Law." This canon deals chiefly though not exclusively with the role of the lawyer as advocate, and virtually all of its constituent black-letter rules concern the advocate's function. Hence, the provision concerning fraud seeins by its placement to have to do with fraud in connection with litigation. The text of the rule also conveys that impression:

A lawyer who receives inforination clearly establishing that ... his client has, in the course of the representation, perpetrated a fraud upon a person or tribunal shall promptly call upon his client to rectify the same, and if his client refuses or is unable to do so, he shall reveal the fraud .... ${ }^{19}$

Apart from the possibility that the exception is hinited to fraud in con-

16. It is surely odd to hold that a lawyer has no obligation to frustrate an as yet unfulfilled fraudulent scheme of his chent, but has an obligation to reveal past fraud. Canon 37, dealing with crimes, takes just the opposite view, i.e, it permits disclosure of intended crimes but not past ones. If canon 41 were taken literally, it would mean that a lawyer could not defend a suit charging fraud unless satisfied that the client was innocent. Such a rule is not inconceivable, or even necessarily inconsistent with an adversary system, but it seems unlikely to have been what the bar intended.

17. ABA Code of Professional Responsibility, Disciplinary Rule (DR) 4-101(B)(1). See also id., Canon 4: "A Lawyer Should Preserve the Confidences and Secrets of a Client."

18. Id. DR 4-101(C)(3).

19. Id. DR 7-101(B)(1). 
nection with litigation, however, this provision essentially corresponded to old canon 41 . It thus would exclude past fraud, though apparently not future fraud, from the coverage of the veil of professional secrccy.

But the bar did not long adhere to this position. In 1974, it added the qualification "except when the information is protected as a privileged communication." 20 On its face this is a profoundly ambiguous provision. If it is intended to mean that disclosure of fraud is not permitted when the rule of attorney-chent privilege prohibits disclosure, then it means very little indeed. This is because, as we have seen, the privilege rule in most states does not confer secrecy on fraud except for revelations by an accused in connection with defense of a criminal prosecution. $^{21}$ It is unlikely that the bar imtended the ainendment to have so hittle meaning. Indeed, the legislative history indicates that what the bar meant to do was to narrow the fraud exception and thus enlarge the domain of secrecy. ${ }^{22}$

This purpose was fully effectuated via interpretation by the A.B.A. Committee on Professional Ethics im an opinion ${ }^{23}$ holding that the term "privilege" in the exception to the confidence rule meant "confidence or secret," as defined in the Code of Professional Responsibility. "Confidence or secret" as defined in the Code of Professional Responsibility is a much more inclusive term than "privilege," extending to "information protected by the attorney-client privilege under applicable law, and . . . other information gained in the professional relationship that the client has requested be held inviolate or the disclosure of which would be einbarrassing or would likely be detrimental to the chent."24 The effect of the opmion, therefore, is to enshroud with secrecy anything a lawyer learns tliat might be "embarrassing . . . or detrimental" to the client. That doesn't exclude much.

Perhaps this is as the rule ought to be. There are respectable and vociferous supporters of the proposition that anything a lawyer learns about his client ought to be secret, maybe even including the client's

20. Id. $\mathrm{DR} 7-102(\mathrm{~B})(1)$, as amended.

21. See United Services Automobile Ass'n v. Werley, 526 P.2d (Alaska 1974). The fraud there was described as "ongoing." But every fraud is "ongoing" nntil uncovered. Hence, under that formulation of the privilege rule, secrecy does not attach to matters of fraud presently in civil hitigation.

22. For a thoughtful discussion of DR 7-102(B)(1), as amended, mcluding its legislative history, see Note, Client Fraud and the Lawyer: An Ethical Analysis, 62 Min. L. Rev. 89 (1977).

23. ABA Comm. on Ethics and Professional Responsibility, Opinions, No. 341 (1975).

24. ABA Code of Professional Responsibility, DR 4-101 (A) (emphasis added). See also text accompanying note 17 supra. As an act of interpretation, opinion 341 took some doing, because it construed the term "privilege" to incorporate the whole of a provision conjunctively referring to "privilege" and "secret." It has to be recognized that opinion 341 is only the latest in a series in which the Ethics Committee has oscillated in its approach to revelation of a chent's fraud or perjury. See ABA Comm. on Professional Ethics, Opinions, No. 287 (1953). 
intention to have the lawyer cooperate in an exercise in perjury. ${ }^{25}$ But there are arguments to be made on the other side. ${ }^{26}$

First, there is danger for the practicing lawyer whenever the bar endeavors to enlarge the scope of the confidence rule beyond the scope of the privilege rule as defined by the courts. The courts deny secrecy to conteinplated or ongoing crimes and frauds, and many of them also deny secrccy to future torts generally. Yet the bar would seem to have it that a lawyer is duty-bound to keep everything about a chent secret, save that the lawyer "may" reveal an intended crime. In this scheme of things, what is a lawyer who has knowledge that is not protected by the attorney-client privilege supposed to do?

Assume (1) the chent discloses an intention to kill someone; ${ }^{27}$ or (2) the client insists upon taking the stand when the lawyer knows the testimony will be perjury, ${ }^{28}$ or (3) the client inquires about the coverage of a fire insurance policy in such a way as to indicate an intent to falsify the facts in making a claim under the policy. ${ }^{29}$

In the first case, involving threatened murder or a crime of approximately equal seriousness such as arson, the lawyer who does not try to prevent the act might well be held criminally liable. ${ }^{30}$ In the second case, involving perjury, the lawyer might be liable for fraud. ${ }^{31}$ And in the third case, the lawyer need do little more than give an opinion on a

25. See Freedman, Professional Responsibility of the Criminal Defense Lawyer: The Three Hardest Questions, 64 Mich. L. Rev. 1469 (1966). Professor Freedman does not seem to have faced the question whether a lawyer, if requested by his chent, is bound to give advice as to the line of perjury that would most likely escape refutation by the prosecution. It is not clear why this result does not follow from his premises.

26. The bar itself presently holds to a position at least partly on the other side, requiring counsel to "reveal the expressed intention of his chent to commit a crime . . . if the contemplated crime is one which would seriously endanger the tife or safety of any person or corrupt the processes of the courts and the lawyer beheves such action on his part is necessary to prevent it." ABA Project on Standards for Criminal Justice, The Defense Function \& 3.7(d) (1971).

27. See Tarasoff $v$. Regents of the University of California, 17 Cal. 3d 425, 551 P.2d 334, 131 Cal. Rptr. 14 (1976).

28. See Annot., 64 A.L.R. 3d 385 (1975).

29. See Fidelity-Phenix Fire Ins. Co. v. Hamilton, 340 S.W.2d 218 (Ky. 1960).

30. By the terms of the Code of Professional Responsibility, the lawyer is permitted to reveal the client's purpose, see DR 4-101(C)(3), and is required to do so under the ABA PROJECT ON Standards for Criminal Justice, The Defense Function. See note 26 supra. Assuming therefore, that no ethical inhibition prevents disclosure, and assuming the foreseeable consequence of nondisclosure will likely be death or devastation, the lawyer can avoid liability only if therc is no "special duty" to act. But the fact of being privy to such a secret may itself give rise to such a duty. Furthermore, a lawyer has an ethical duty to try to dissuade a client from cominitting a crime. That in itself can be the basis of a "special duty" to act if attempts at dissuasion are meffective.

31. The weight of authority appears to be that a conspiracy to adduce false testimony is not actionable. See Annot., 31 A.L.R. 3d 1423 (1970). But there may be liability if the use of false testimony is a means to another wrongful end, see id. at 1438, which it almost mevitably is. And the weight seems to be shifting. See, e.g., Roberts v. Ball, 57 Cal. App. 3d 104, 128 Cal. Rptr. 901 (1976). 
stated set of facts to become involved in the client's scheme. ${ }^{32}$

In sucl situations, a lawyer may have to make a disclosure in order to avoid personal liability. Perhaps it is sufficient to say that under certain circumstances a lawyer "may" reveal the confidence, although it would be well if the Code extended this option to frauds for which the lawyer might be held responsible as well as to crimes. But the law holds the lawyer liable in these circumstances because it is as wrong for the lawyer to permit the wrong as it is for the client to commit it; the lawyer is an accessory. Yet the rule permits the lawyer who thinks the client can get away with the intended act not to disclose. ${ }^{33}$ That is surely a peculiar posture for officers of the legal system.

Contemplation of these consequences imspires another observation about the bar's present position. In its opinion ${ }^{34}$ giving broad construction to the rule of secrecy, the A.B.A. Committee on Professional Ethics stated that such a construction rests on a "tradition" in which the value of confidentiality "should take precedence." And in support of this proposition the opinion refers to the "many annotations to DR 4-101." In terms of running inches, most of the annotations are to earlier A.B.A. opinions. Relatively little caselaw is cited, and the notes rely chiefly on Wigınore. ${ }^{35}$ But both the earlier A.B.A. opinions expressing the bar's rule on "confidence," and Wigmore's synthesis of the rule of "privilege," are ultimately derived from the decisional law establishing that "privilege" should be accorded to "confidences" between client and lawyer. An exammation of that law indicates that the "tradition" is not quite what the bar may think it is.

\section{II}

\section{The "Tradition"}

Wigmore says of the privilege:

The history of this privilege goes back to the reign of Elizabeth, where the privilege already appears as unquestioned .... The policy of the privilege has been plainly grounded, since the latter part of the $1700 \mathrm{~s}$ . . . . In order to proinote freedom of consultation of legal advisors by

32. See SEC v. Frank, 388 F.2d 486 (2d Cir. 1968). Moreover, a client who would consult an attorney about swindling a fire insurance company is unlikely to have compunctions, if caught, against swearing that the lawyer put him up to it. Should lawyers have to wait for that to happen? Cf. DR 4-10I(C)(4): "A lawyer inay reveal . . . confidences or secrets necessary . . . to defend himself . . against an accusation of wrongful conduct."

33. The annotation to DR 4-10I also does not cite or deal with ABA COMM. ON PROFESSIONAL ETHICs, OpINIONS, No. 287 (1953). That decision held that a lawyer need not reveal fraud on a court in connection with a divorce proceeding, but the opinion had to dispose of conflicting prior A.B.A. opinions and was accompanied by a trenchant dissent. Thus, to say in 1975 that there is a "tradition" dating back to 1953 is to foreshorten time rather severely in a profession as old as ours.

34. ABA Comm. on Professional Ethics, Opinions, No. 341 (1975).

35. $8 \mathrm{~J}$. WIGMORE, supra note $8, \S 2290$. 
clients, the apprehension of compelled disclosure by the legal advisers must be removed; and hence the law must prohibit such disclosure except on the client's consent. ${ }^{36}$

There is something to this. Elizabethan cases do indeed refer to the privilege, ${ }^{37}$ and although some of the early cases express the idea that the privilege was that of the lawyer (a gentlemen does not give away matters confided to him), as the rule developed the privilege became that of the client to have his secrets protected. It is also true that in order to prevent disclosure, the law must prohibit it, for otherwise the lawyer would be governed by the general rule that a witness must give evidence of facts within his knowledge.

But beyond this, the historical foundations of the privilege are not as firm as the tenor of Wigmore's language suggests. On the contrary, recogmition of the privilege was slow and halting until after 1800 . It was apphed only with much hesitation, and exceptions concerning crime and wrong-doing by the client evolved simultaneously with the privilege itself. At least in the English cases, an exception to the rule was usually found if proof aliunde indicated that the chent was indeed engaged in some malfeasance. Taken as a whole, the historical record is not authority for a broadly stated rule of privilege or confidence. It is, rather, an invitation for reconsideration.

\section{A. The Early Cases}

Aside froin fragmentary references from the Elizabethan period, the reported decisions involving the privilege begin in 1654 . In the period from that year until 1743, almost a century, there are fourteen reported decisions on the subject. In some of the cases the witness was allowed to withhold his testimony, at least as to some matters, but on grounds that reveal considerable doubt about the scope of the privilege. In the others the claim of privilege was denied.

In analyzing these early cases it is important to keep in mind the distinction made in England between barristers, on the one hand, and attorneys, solicitors, and scriveners, on the other hand. In general, barristers presented the evidence and argued the law in court; attorneys and solicitors prepared cases for litigation, advised chents, and drafted documents; scriveners enscribed documents and may also have given advice on the side. It appears that the term "counsel" was used to refer to barristers, although that term or the term "counselor" may sometimes liave been used to refer to attorneys and solicitors. There inay have been soine overlap of function then as now; in any event the division of functions within the legal profession had not yet assumed its

36. Id. $\$ \S 2290,2291$.

37. See cases cited in id. $\$ 2290$, at 542 n.l. 
present form..$^{38}$ Nonetheless, the distinction is of functional, doctrinal, and conceptual significance in understanding these cases.

Functionally, a barrister-as a presenter of evidence and argument—ordinarily could learn the facts about a dispute only upon being "briefed." If he were to be deposed as a witness, in the usual case it would necessarily impair the functioning of the adversarial systein. However, such would not necessarily be the effect of receiving the testimony of an attorney, whose functions included not only preparation of litigation but also the giving of legal advice. Put differently, allowing the privilege with regard to barristers but not attorneys inight be the equivalent of allowing the privilege with respect to communications with a direct connection to litigation but not with respect to other natters revealed to a lawyer.

Doctrinally, the cases in this period more readily give effect to the privilege when it is invoked by "counsel" than when it is invoked by an attorney or a scrivener. This may reflect a class distinction between barristers and other "lawyers" but it also seeins to have something to do with the peculiar function of the barrister.

Conceptually, the distinction inay explain why at one time the privilege was thought to belong to the lawyer rather tlian the client. A barrister was considered not inerely an "officer" of the court but a meinber of it, who could no inore properly be asked to reveal a client's confidences than a modern judge could be asked to disclose natters heard in camera. ${ }^{39}$

Two of the early cases allowed a "counselor" to refuse to testify" and two extended the privilege respectively to an "attorney" and to a "solicitor." In contrast witlı these few cases ${ }^{42}$ is a larger number in

38. See 6 W. Holdsworth, A History OF ENGLish LAw, ch. viii (2d ed. 1937).

39. Cf. $8 \mathrm{~J}$. WIGMORE, supra note $8, \S 2290$. Wigmore explained the transformation of the privilege from that of the lawyer to that of the client as a transformation of the underlying theory from "objective" to "subjective." It seens at least equally plausible to attribute the change in the "holder" of the privilege to the fact that the privilege came to extend to communications not only to barristers, who stood as members of the court, but also to attorneys, who did not.

40. Walfron v. Ward, Style 449 (K.B. 1654) ("a Counsellor at the Bar was examined upon his Oath to prove the death of Sir Thomas Conye. Whereupon Serjeant Maynard urged to have him examined on . . . some matters whereof he had been made privy as of Counsel in the cause. But Roll Chief Justice answered, $\mathrm{He}$ is not bound to make answer for things which inay disclose the secrets of his Client's cause, and thereupon he was forborn to be examined."); Bulstrod v. Letchmere, Freeman 5, 22 Eng. Rep. 1019 (Cl. 1676) ("the defendant, being a counsellor at law, shall not be bound to answer concerning any writings which he hath seen, nor for any thing which he knoweth in the cause as counsellor . . . . [B]ut a case was cited in Bridgman's time . . that they being but scriveners should not have that privilege and the Lord Chancellor made it a doubt, if a thing were revealed, under the condition of secrecy, to one that was not a barrister, whether or not he would oblige him to answer.").

41. An "attorney" was allowed to refuse to testify concerning an agreement he had drawn between a sheriff and under-sheriff, to prove it a corrupt agreement, "though he was not a Counsellor," in Anon, Skinner 404 (K.B. 1694). This may be a case of a right not to incriminate one's self, given the nature of the attorney's mvolvement. In The King v. Watkinson, 2 Strange 1122 
which the lawyer's testimony was allowed, some of which involve "counsel." The case of Spark v. Middleton ${ }^{43}$ is particularly illummating as to why these cases held that the testimony was not privileged:

Mr. Aylet having been Counsel to the Defendant, desired to be excused to be sworn on the General Oath, as Witness for the plaintiff. . . which the Court after soine dispute granted; and that he should only reveal such things as he either knew before he was Counsel, or that came to his knowledge since by other persons, and the particulars to which he was to be sworn were particularly proposed, viz., What he knew concerning a Will in question ... and the Court only put the question, Whether he knew of his own knowledge. ${ }^{44}$

It is to be observed that the witness' objection in Spark v. Middleton is to being sworn on the General Oath, ${ }^{45}$ and the upshot is that the lawyer is required to answer only certain questions. The questions may concern matters "he knew before he was Counsel, or that came to his knowledge since by other persons," and matters which "he knew of his own knowledge." These terms sketch out boundaries of the privilege that later came to take firmer form: The privilege applies only to matter learned while counsel, not "before" or "since"; perhaps not to matter learned from a source other than the client;"46 and not to matter within counsel's "own knowledge," i.e., that which the lawyer observed as distinct from having been told by the chent. ${ }^{47}$

(K.B. 1740), a prosecution for perjury in testimony at a chancery deposition, the defendant's solicitor was called to identify him as the deponent. "But he [i.e., the solicitor] insisting on his privilege, the Chief Justice would not compel him to be sworn: so the defendant was acquited [sic]." The fact that the solicitor was in this case performing a role akin to that of advocate could explain why his testimony was treated as privileged.

42. The only other cases im this period clearly sustaming an objection to the testimony of a lawyer, in both mstances an attorney, seem to have nothing to do with privilege. In Legard $v$. Foot, Rep. temp. Finch 82, 23 Eng. Rep. 44 (Ch. 1673), an "attorney and solicitor" was made the subject of a bill of discovery concerning his handling of the affairs of a person since deceased. He objected that the matter was none of the plaintiffs busmess. Defendant said "that he faithfully managed the said Causes for his Client, and ought not to make any Discovery thereof to the Plaintiff, im Regard he was not a Party to any of the Causes, neither is the Plaintiff capable in any Sort to call the Defendant to Account concerning the Same." The claim of privilege seems to have been thrown in for good measure. In Harvey v. Clayton, 3 Keb. 139, 84 Eng. Rep. 640 (Ch. 1675), noted in 2 Swanst. 221 (1818) as being in Nottingham's manuscript, discovery was denied from a "scrivener" concerning the source of the funds provided under a mortgage, on the ground that plaintiff had no good reason for the discovery ("it was safer for the plaintiff to be ignorant"), while disclosure would be injurious to defendant ("it may be a ruin to the Defendant, in his trade, to discover it; for no man thereafter will employ him").

43. 1 Keb. 505, 83 Eng. Rep. 1079 (K.B. 1664). See also The King v. Watkinson, 2 Strange 1122 (K.B. 1740).

44. 1 Keb. at 505, 83 Eng. Rep. at 1079.

45. An "oath to tell the truth, the whole truth, and nothing but the truth . . . instead of the 'suppletory oath', a more restricted oath, to make just and true answers to such questions as shall be asked by the court." 18 Words AND PHRAsEs 421 (1956).

46. See Valliant v. Dodemead, 2 Atk. 523, 524, 21 Eng. Rep. 203 (Ch. 1743) (claim of privilege innst state "that counsel knew nothing but by the information of his client").

47. See Spencer v. Luttrell, I Nottimgham's Chancery Cases, no. 150 (1673), 73 Seld. Soc'y 
In other cases, testimony was elicited from a witness who liad acted as a legal advisor or legal draftsman. ${ }^{48}$ Most important of these is perhaps the decision of the House of Lords in Radcliffe v. Fursman ${ }^{49}$ Althougli the witness in the case was referred to as "counsel" and lience apparently was a barrister, the testimony souglit related to the giving of legal advice rather than the representation of a client at trial. ${ }^{50}$ The argument against admissability was that a client's communications witl counsel are "intended for private instruction and information only, in order to direct parties in the conduct of their affairs . . . no counsellor or attorney can be obliged, or ought to discover any matter whicl his client reveals to him ...."51 The opposing argument was that always offered against a claim of privilege-that disclosure would yield the trutli ${ }^{52}$-and that argument prevailed.

\section{B. Annesley v. Anglesea}

If the rule of attorney-client privilege was narrowly defined and tenuously established before 1743, it was nearly wiped out by the case of Annesley $v$. Anglesea, ${ }^{53}$ decided that year. This case reads like a source material for a Dickens novel-indeed, its facts inake David Copperfield seein a pale contrivance. The legal setting is an action of

110 (1957), also referred to in the reporter's note in 2 Swanst. 221 (1818) ("counsel" required to testify whether a debt was satisfied). See also Stanhope v. Nott (no date), referred to in 2 Swanst. 221 (1818) ("counsel" who says he does not have possession of deeds inust in discovery proceeding tell to whoun he gave them, "for otherwise, deeds having been played into the hands of a counsel might be suppressed"); Lord Say and Seal's Case, 10 Mod. 40 (K.B. 1712) (attorney called to prove that a deed was executed on some other date than it purports to have been; the matter "could not be called the Secret of his Chent, that it was a Thing he might come to the Knowledge of without his Client's acquainting him ...."); Valliant v. Dodemead, 2 Atk. 523, 524, 21 Eng. Rep. 203 (Ch. 1743) (attorney called to identify an assignment drafted by him).

48. See, e.g., Rothwell v. King, I Notthingham's Chancery Cases, no. 68 (1673/74), 73 Seld. Soc'y 32 (1957), also referred to in 2 Swanst. 221 (1818) ("the trust of a counsellor doth not extend to the suppression of wills"); Atterbury v. Hawkins, II Nottingham's Chancery Cases, no. 663, 79 Selden Soc'y 498 (1961) ("a scrivener is not a civil confessor as a lawyer nor to be so treated"). But cf. cases cited in note 42 supra.

49. 2 Bro. P.C. 514, 1 Eng. Rep. 1101 (1730).

50. The suit was to uncover defendant's failure to pay anounts due on an annuity which plaintiff beheved was still payable but whose terms defendant had refused to disclose. Counsel was asked to testify to a supposedly hypothetical case stated to him by his client, involving the question whether the chent would have an obhigation on those facts. The hypothetical included enough details corresponding to the already proven facts to compel the inference that, if the chient had indeed stated such a hypothetical to counsel, it amounted to an admission of a breach of trust as alleged by the plaintiff.

51. 2 Bro. P.C. at 516, 517.

52. "No inconvenience could possibly arise to [the defendant] making such discovery, but paying the bonds, upon its appearing that they were really due." Id. at 517 .

53. 17 How. St. Trials 1139 (1743). The caption of the case is properly Craig $\boldsymbol{r}$. Anglesea, but it has not usually been so styled in subsequent citation and will not be labelled such here. See 8 W1GMORE, supra note $8, \S 2291$. Wigmore quotes extensively front Annesley $v$. Anglesea, but not completely; his rendition is such, indeed, that one does not learn that the case resulted in a refusal to apply the privilege. 
ejectment im which the plamtiff claims lands as the lessee of James Annesley and the defendant claims on the basis of a superior title. The question of title depended on whether James Annesley or the defendant, Richard Earl of Anglesea, was the owner of the lands by inheritance from Arthur, Baron of Altham. Although suits of ejectment were conventionally brought to determine title, Annesley v. Anglesea was framed as a trial of title in order to determine a more sinister issue. The defendant Earl concededly was the brother of Arthur of Altham and his rightful heir if Arthur had died childless. But James Annesley claimed to be Arthur's long lost son, born of Arthur's lawful wife but then put out of his father's house by a jealous step-1nother, left penniless to fend for himself in Dublin and London after his father's death, transported to a remote colony under indenture from which he could not escape for soine 13 years, prosecuted (unsuccessfully) for murder at the instance of his scheming uncle, the defendant, and finally rescued and enabled to assert his rightful claims by the loyal testimony of old nurses and retainers.

The question of attorney-client privilege arose in connection with the matter of the murder prosecution. The plaintiff asserted that the defendant Earl knew of young James and that he was Arthur's rightful heir, that the defendant wanted James done away with, by legal hangmg if possible, that the defendant revealed this knowledge and imtention to his attorney, that the defendant engaged the attorney to procure the prosecution of James for murder, well knowimg that the homicide in question was an accident, and that all this was for the purpose of putting James out the way as claimant to the " 30 messuages, 30 tofts, 50 cottages, 2 mills, 50 gardens, 800 acres of arable land, 300 acres of meadow, 600 acres of pasture . . . with the appurtenances" that were the inheritance in question. ${ }^{54}$ Plaintiff offered to prove the procurement of the prosecution through the testimony of John Giffard, who was the attorney involved.

In the voir dire of Giffard it appeared that he had acted as attorney for the defendant in various litigation and other matters from time to time over a period of twenty years prior to 1742, that in May of 1742 defendant suminoned Giffard and asked him to set in motion a murder prosecution against James, and that in the course of the conversation the defendant made statements indicating that he knew James to be Arthur's son (the immediate issue in the case) and that he would "give $£ 10,000$ to have him hanged."5s It was necessary to address the question of privilege to determine whether any of this could be offered in evidence.

54. 17 How. St. Trials at 1141 .

55. Id. at 1224-28. 
Both sides acknowledged a general principle to the effect that information coming to the knowledge of an attorney in connection with the representation of a chent is not subject to disclosure. Their dispute focused on whether a inore precise definition of the privilege would mclude or exclude matter of the sort that Giffard had learned. The arguments of the parties and the reasoning of the court warrant careful analysis, both because they reveal how unforined the rule of privilege was at the tine and because they anticipate substantially everything that has simce been said on the subject.

The plaintiff's position rested on three arguments. The first was that the information to be ehicited from the attorney Giffard was not imparted to him in connection with the pending action. ${ }^{56}$ In other words, the scope of the privilege should distinguish between confidential communications "directly" related to the pending case and coinmunications only "indirectly" related. Obviously, there would have to be soine connection between the transaction in which the cominunication occurred and the pending case, or else the communication would be excluded simply on grounds of irrelevance. The argument, therefore, must be that the cominunication froin the Earl to Giffard about the murder prosecution was not made in furtherance of the Earl's purpose of preparing his defense of the immediately pending suit. And this in turn imples that the rule of privilege should be confined to coininunications in furtherance of pending litigation, or perhaps to anticipated hitigation, and not extend to cominunications whose purpose is to obtain advice or assistance apart from pending litigation, for example in business dealings and other transactions. ${ }^{57}$ That such was indeed the argument is suggested by the fact that defendant argued that the privilege should extend both to obtaining advice and retaining an advocate.

Plamtiff's second argument for disclosure was that the information to be ehicited from the attorney was not essential to the inatter in which the attorney was consulted. ${ }^{58}$ This argument would conceive the attorney and chent as having two sets of roles or capacities in which they cominumicate with each other. First, they are respectively attorney and client; second, they are acquamtances or friends. The privilege attaches to such coinununications between the participants as are gerinane to their roles as attorney and client, but not to commumications outside these roles. This argument was then fortified by the further proposition (considered below) that plotting a baseless prosecution could not be within the legitimate annbit of the attorney-client relationship. But the

56. Id. at $1229,1232$.

57. Furthermore, since the communication was made in furtherance of the now terminated murder prosecution, the argument necessarily implies that the duration of the privilege should not extend beyond the pendency of the litigation to which the communication relates.

58. 17 How. St. Trials at 1230. 
argument has coherence of its own. It simply states that communications are not privileged merely because the participants have a relationship of lawyer and client; the communication must concern matters pertinent to that relationship.

This limitation on the scope of the privilege is echoed in modern law. The standard formulation is that communication between persons standing in the relation of attorney and client is privileged only if it is made "in the course of" 59 that relationship. The difficulty in applying this limitation in modern law arises from the fact that lawyers today perform such a wide range of services that it is difficult to say when the consultant has stopped being a lawyer and has beconie a financial advisor, inarriage counselor, or whatever. However, the term "legal" advice can be used not only in contradistinction to "business" advice, etc., but also in contradistinction to matters that, because they involve wrongful conduct, cannot be considered properly within the lawyer's role, however broadly defined.

This is apparently what counsel in Annesley $v$. Anglesea had in mind: A client's disclosure is not privileged if it relates to achieving a purpose to which the lawyer could not lend his assistance. This is akin to but different from the proposition that the privilege does not attach to disclosure of a proposed crime or wrong that the client intends. The difference arises because sonve forms of conduct are prohibited of an attorney but not of his client. For example, a client may be legally innocent in seeking a criminal prosecution so long as lie acts in good faith, while a lawyer might be held to the higher standard of acting both in good faith and with reasonable cause, defined as grounds that a professionally conipetent lawyer would recognize as sufficient. Similarly, a lawyer has a duty not to mislead a court, while the corresponding duty in clients is merely that they not be untruthful. ${ }^{60}$

The third argument for disclosure was that the privilege should not apply to a communication revealing the client's intention to commit a wrong: "a secret, which is contrary to the public good, such as a design to commit treason, inurder, or perjury";,61 "a crime"; 62 or "a thing that is 'malum in se,' against the common rules of morality and hon-

59. See C. MCCoRMICK, supra note 5, $\$ \S 87-88$.

60. In practice today, this limitation on the privilege would be difficult to apply. Yet at a minimun it discourages communications to solicit a lawyer to perform unprofessional acts. The bar in this country today apparently considers that such client explorations should be protected by secrecy. See notes 17-22 and accompanying text supra. As a result, some lawyers' offices have become a good place to take really dirty proposals for a review of their practical feasibility. This, of course, can only harm the general reputation of the bar. The legal profession thus pays a heavy price for the self-imposed rule that lawyers must suffer in silence any proposal that they compromise their professional integrity.

61. 17 How. St. Trials at 1229.

62. Id. at 1231 . 
esty."63

Any one of these characterizations would have fit some part of the defendant Earl's conduct. Counsel for plaintiff pointed to the Earl's proposal of a false prosecution, to his offer of $£ 10,000$ to procure James' hanging, and to his aim to "see a man kept out of his estate and honour [i.e., title as baron of Altham], and all that is dear to him.."64 For purposes of plaintiff's argument, there was no need to particularize, and indeed the force of the argument was inade stronger by luinping together all three wicked acts. But consideration of each of the proposed acts separately reveals that they involve somewhat different degrees of moral and legal obloquy.

The aim of seemg James dead can be characterized euphemistically as an intention to commit a crime involving serious personal harm, and thus involves the elements of both criminahity and gross wrongfulness. The plan to procure a false prosecution of inurder is a ineans to that same end, hence is tinged with the same elements of wrongfulness, and also involves corruption of the administration of justice. Although corruption of justice is a lesser evil than procurement of nurder, it is a serious offense and one that a lawyer might be regarded as having a special obligation to intercept, especially a lawyer who is invited to bc the instrument of corruption.

The fraudulent aim underlying the Earl's conduct-to secure the estate for himself and, correlatively, to deprive Jaines of his rightful inheritance-could itself be considered sufficient to deprive the Earl's communication of the protection of secrecy, if the privilege does not apply to plans of a client involving fraudulent gam for himself or infliction of injury through fraud on another.

Defendant's general formulation of the privilege was, not surprisingly, ratler different. His basic thesis was that all communications between client and attorney are privileged, with some possible exceptions. The argument rested on three points: First, that the privilege is not merely that of the attorney to inamtain his honor by keeping a client's seerets, but is a privilege of the client agamst disclosure of those secrets. Second, that the cases relied on by the plaintiff, wlierein disclosure had been allowed, were distinguishable in that they fell within recognized exceptions to the privilege. And third, that the policy behind the privilege required its application in the case at hand.

Counsel's argument expressed the policy supporting the position that the privilege is the client's, as well as the attorney's, as convincingly as it has been stated since:

As to the client, the interest which he has in the privilege, is very obvi-

63. Id. at 1232 .

64. Id. at 1231 . 
ous. No man can conduct any of his affairs which relate to matters of law, without employing and consulting with an attorney; even if he is capable of doing it in point of skill, the law will not let him; and if he does not fully and candidly disclose every thing that is $\mathrm{m}$ his mimd, which he apprehends may be in the least relative to the affair he consults his attorney upon, it will be impossible for the attorney properly to serve him: therefore to permit an attorney, whenever he thinks fit, to betray that confidence ... would be of the most dangerous consequence, not only to the particular chent concerned, but to every other man who is or may be a chent. ${ }^{65}$

As for the scope of the privilege, defendant's counsel observed that "the gentlemen on the other side have attempted to confine and circumscribe this privilege, and to make it extend only to matters disclosed by the client relative to some suit, then pending, in which the attorney is concerned. But I apprehend that this would make the rule a great deal too narrow . . . ."66 Defendant argued that the confidential relationship "must be presumed actually to subsist from the tiine he first retained Mr. Giffard, till the time he discharged him; and whatever my lord said to him during that space of time, touching his affairs, was plainly said to him under confidence as his attorney."67

The court allowed Giffard's testimony to be received. ${ }^{68}$ It suggested that communications between client and attorney are ordinarily, or one imight say prima facie, privileged. Lord Chief Baron Bowes so implied in stating that the question for decision was whether the circuinstances "take the present case out of the general rule." reason for deciding that the case was outside the general rule is not wholly clear. Indeed, the Chief Baron expressed reluctance to fix boundaries, stating that "the proper way will be to determine this and every like case upon their own circumstances." 70 His conclusion in this case apparently rested on the fact that the communication from the Earl as client to Giffard as attorney was not "necessary" to securing the attorney's assistance:

If I employ an attorney, and entrust secrets to him relative to the suit, that trust is not to be violated; but when I depart from that subject wherein I employed him, he is no inore than another man, especially

65. Id. at 1237.

66. Id.

67. Id.

68. The court resolved the question whether the privilege is that of the attorney or of the client by deciding that the client's objection to disclosure is sufficient to raise the issue of privilege. Although Giffard himself was willing to testify, the court declined to treat that as determinative and instead examined the basis of the Earl's objection. See id. at 1242.

69. Id. at 1239.

70. Id. This familiar formula rather clearly signifies that the court had no firm idea of what the general rule ought to be. 
when the cause I did employ him in is over. ${ }^{71}$

This formulation suggests that the privilege applies to matters disclosed in connection witl pending or proposed litigation, but only if it is germane to the attorney's function in the litigation.

Even then, the privilege might be defeated if the matter communicated is necessarily in furtlierance of a wrongful use of litigation. In other words, a communication by a client to an attorney is privileged if it is directly germane to securing assistance im pending or prospective litigation, unless the litigation itself would amount to an abuse of process, but the privilege ceases to apply after the matter in question has been examined at trial. While this is a very narrow formulation of the privilege, it is certainly not imcoherent.

In concurring with the ruling, Baron Mounteney rested his decision partly on the ground that the cominunication was not "necessary" to the matter in which the attorney was retained, and partly on the ground that the communication related to a "highly criminal" act. ${ }^{72}$ Mounteney's treatinent of the term "necessary" is especially interesting because it results in a radically narrow definition of the privilege. The concept of a "necessary" communication between a client and his attorney can be grasped only by understanding the attorney's role in litigation as it was then performed. ${ }^{73}$ This role was essentially the saine as that of the solicitor in modern practice, as intermediary between the client and the barrister. The attorney's function was twofold: to prepare and file the client's case, mcludimg draftimg the pleadings and making appearances; and to inake arrangements on behalf of the client for assistance of counsel (i.e., a barrister) to present the case to the court. Hence, Mounteney would limit the privilege to communications "necessary" to the draftimg of pleadimgs and other litigation docunients. Thus he refers first to the attorney's role:

[I]t is certainly undoubted law, that attornies ought to keep inviolably the secrets of their clients, viz. That an increase of legal business, and the inability of parties to transact that business themselves, inade it necessary for them to einploy (and as the law properly expresses it, ponere in loco suo) other persons who might transact that business for them. ${ }^{74}$

He then refers to the need for secrecy:

[T] his necessity mtroduced with it the necessity of . . . secrecy . . . in order to render it safe for clients to communicate to their attornies all proper instructions for carrying on of those causes. ${ }^{75}$

71. Id. at 1239-40. The Chief Baron went on to say, "Besides, as this was in part a wicked secret, it ought not to have been concealed." Id. at 1240.

72. Id. at 1243.

73. See 6 W. Holdsworth, supra note 38, ch. viii. See also 8 J. Wigmore, supra note 8 , $\$ 2294$.

74. 17 How. St. Trials at 1241.

75. Id. 
And from this he deduces the scope of the privilege:

Whatever either is, or by the party concerned can naturally be supposed, necessary to be communicated to the attorney, in order to the carrying on any suit or prosecution ... [ [is protected]. On the other hand, whatever is not, nor can possibly by any nuan living be supposed to be, necessary for that purpose [is not protected]. ${ }^{76}$

In short, Mounteney's definition would limit the privilege to disclosures that are reasonably relevant to the subject matter of pending or contemplated litigation and which the attorney might legitimately use in preparing tlue litigation. ${ }^{77}$

\section{Fall and Rise of the Privilege}

For 50 years after 1743 there appears to be no reported decision clearly sustaining a claim of privilege, ${ }^{78}$ although there are cases permitting an attorney to refuse to supply documents in response to a subpoena. $^{79}$ In several cases attorneys were obliged to testify to facts coming to their knowledge by observation as distmct from matters described to them by clients. ${ }^{80}$ In a couple of other cases, the testimony was received because the communication was deemed outside the scope of imstructions necessary for litigation. For example, im Cobden $v$. Kendrick ${ }^{81}$ m 1791, plamtiff in an action on a contract disclosed to his attorney after judgment that the contract was for a gambling debt and hence unenforceable. In a subsequent suit for restitution of the amount paid on the judgment, the opposite party was allowed to prove this conversation. The court commented:

The difference is whether the communications were nuade by the client

76. Id. 44.

77. The third judge, Baron Dawson adopted the same approach as Mounteney. Id. at 1243-

78. Indeed, in Maddox v. Maddox, 1 Ves. Sr. 61,27 Eng. Rep. 892 (Ch. 1747), it was said: Though an attorney or counsel concerncd for one of the parties inay, if he pleases, demur to his being examined as a witness; yet if he consents, the court will not refuse the reading his deposition. This objection has often been made; and though some particular judges have doubted, it is now always overruled.

Id. at 63. But in Bishop of Winchestcr v. Fournier, 2 Ves. Sr. 445, 28 Eng. Rep. 284 (Ch. 1752), there is a passing note that testinony of one of the witnesses should not have been received, because "no counscl, attorney, or solicitor should betray the secrets of their clients, and might demur to their interrogatories." Id. at 447. It is of course possible that as a matter of professional courtesy attornies were in practice not called as witnesses except when no other proof was available.

79. See, e.g., Tex v. Dixon, 3 Burr. 1687 (K.B. 1765); Wright v. Mayer, 6 Ves. Jun. 280, 31 Eng. Rep. 1051 (Ch. 1801); Stratford v. Hogan, 2 Ball. \& Beat. 164 (Ir. Ch. 1812). This apparently was just a problein of forn, because a subpoena addressed to the party would reach documents in the possession of his attorney. Wright v. Mayer, 6 Ves. Jun. 280 (Ch. 1801). See also Copeland v. Watts, 1 Starkie 95, 171 Eng. Rcp. 412 (C.P. 1815).

80. Doe ex dem. Jupp v. Andrews, Cowp. 845 (1779) (attorney was subscribing witness to land contract); Duffin v. Sinith, Peake 108 (K.B. 1792) (attorney called to testify as to a bond he drafted, to prove it was usurious); Sandford v. Remington, 2 Ves. Jun. 189 (Ch. 1793). See Spark v. Middleton, 1 Keb. 505 (K.B. 1664), for precedent on this point.

81. 4 T.R. 431, 100 Eng. Rep. 1102 (K.B. 1791). 
to his attorney in confidence as instructions for conducting his cause, or a mere gratis dictum. The former was not the case here: on the contrary, the purpose in view had been already obtained; and what was said by the chent was in exultation to his attorney for having before deceived him as well as his adversary. ${ }^{82}$

At the turn of the century, the privilege began to fare better. It was sustained in a case mvolving the very matter that Annesley $v$. Anglesea had left protected-a statement by the chent to counsel of facts necessary to prosecute or defend a suit. ${ }^{83}$ There are also four decisions sustaining the privilege by Lord Ellenborough, who evidently was both a strong advocate of the privilege and very loose, or even imcompetent, in his legal analysis. He defied precedent ${ }^{84}$ to hold that an attorney could not testify as to facts learned of his own observation, even where the matter im question was a transfer in fraud of creditors. Similarly dubious was his holding that an attorney could not be exainined about a message he dehvered to the opposite party in a transaction. ${ }^{85}$ Most ainazing of all, he initially held (only to reverse himself later) that an attorney could not be examined as to whether he had received a discovery notice served on him by an opposing party. ${ }^{86}$

Two cases followed involving comununications by a client to his attorney concerning imminent litigation. ${ }^{87}$ These cases affirm the important point that the privilege apphes even though the suit may not yet have been filed, but they still require that the communication be within the rubric of "imstruction" concerning a lawsuit. In yet another case the court sustained the privilege as applied to a consultation for the purpose of drafting a document (not litigation) and a transaction allegedly in fraud of creditors. ${ }^{88}$ Other cases, however, continued to hold

82. Id. at 432, 100 Eng. Rep. at 1103. See ABA Comm. ON Professional Ethics AND Professional Responsibility, OpInions, No. 287 (1953). See also Wilson v. Rastall, 4 T.R. 753, 100 Eng. Rep. 1283 (K.B. 1792), which has a strong dictum by Buller, J., in support of the privilege but nonetheless holds the attorney's testimony not privileged on the facts, apparently because the communication was not from the client but from a third person.

83. Sloman v. Herne, 2 Esp. 695, 170 Eng. Rep. 499 (K.B. 1798). The attempt to ehcit the attorney's testimony had an arguable basis in the fact that the communication was not actually from the party to the suit but from one "virtually the same" in interest.

84. Robson v. Kemp, 5 Esp. 52, 170 Eng. Rep. 735 (K.B. 1803); Brard v. Ackerman, 5 Esp. 119,170 Eng. Rep. 758 (K.B. 1804). Cf. cases cited in notes 43 and 47 supra. See also Bramwell v. Lucas, 2 Barn. \& Cress. 745, 107 Eng. Rep. 560 (K.B. 1824), discussed in note 90 infra.

85. Gaimsford v. Grammar, 2 Camp. 9, 107 Eng. Rep. 516 (K.B. 1809).

86. Spenceley v. Schullenburgh, 7 East 357, 103 Eng. Rep. 138 (K.B.1806).

87. Hughes v. Biddulph, 4 Russ. 190, 38 Eng. Rep. 777 (Ch. 1827); Clark v. Clark, 1 M. \& Rob. 3, 174 Eng. Rep. 2 (K.B. 1830).

88. Cromack v. Heathcote, 2 Brad. \& B. 4, 129 Eng. Rep. 857 (C.P. 1820) (Common Pleas). Dallas, C.J., said:

The Plamtiff came to employ Smith as an attorney, though Smith happened to refuse the einployment. . . . Is not this a consulting on professional busmess? One is staggered at first being told that there are decided cases which seem at variance with first primciples the most clcarly established; but the cases cited do not at all bear out the proposition 
that the attorney's evidence may be received, for example, to prove the identity of a client for whom he prepared a partnership agreement, ${ }^{89}$ or to prove that the client was skulking in the attorney's office to avoid arrest by his creditors. ${ }^{90}$

Perhaps the most startling of all the holdings in this period, given our modern conception of the privilege, is Preston v. Carr. ${ }^{11}$ This was a suit for specifie performance in which plaintiff demanded production from the defendant of letters written to his sohcitors. The letters set forth facts with a view to their being presented to counsel (i.e., a barrister) for an opinion whether the contract was binding in the circumstances. It was held that the letters had to be produced, although counsel's opinion in response need not be. In other words when a communication to an attorney can be proved by some means other than the attorney's own testiniony, the privilege does not apply. As the Chief Baron said, "I cannot accede to the proposition . . . that the privilege of an attorney is the privilege of the chent, to the extent that the client himself may ... avoid discovering commumications which have passed between him and his solicitor."992

At first inipression it is astomishing that a chent's letters to his solicitor relating to imminent hitigation could be obtained by discovery. What could more clearly be a "confidential commumication"? Upon reflection, it becoines evident that the point of the court's opinion must be that the chent cannot claim a privilege against yieldimg his own knowledge about the matters in controversy simply because he has related them to his solicitor. True, privilege precludes the solicitor from giving evidence of the knowledge thus disclosed. ${ }^{93}$ But, reasons the court, since defendant himself would have to disgorge his knowledge on deposition, and simce he would have to produce preexisting memoranda of events such as a diary or correspondence with others, it is no ground for objection that his inemoranda of the events were sent to counsel.

This case brings into sharp relief the importance of the disquahification of parties from being witnesses in proceedings at law at that

contended for, and I know of no such distinction as that arising from the attorney being employed or not employed in the cause.

Id. at 5-6, 129 Eng. Rep. at 858. Either this missed the point that the consultation did not involve prospective hitigation, or else it was a holding that the privilege apphed to "professional business" other than hitigation. If the latter, it was new law. See notes 48-49 supra.

89. Studdy v. Sanders, Dow. \& Ry. 347, 349 (K.B. 1823) (no confidential communication but "a fact . . cognizable to the witness"); Williams v. Mundie, Ry. \& Mood. 34, 171 (K.B. 1824).

90. Bramwell v. Lucas, 2 B. \& C. 745, 749, 107 Eng. Rep. 560, 561 (K.B. 1824) ("Whether the privilege extends to all communications between attorney and chent or not, there is no doubt that it is confined to communications . . . .").

91. 1 Y. \& J. 175, 148 Eng. Rep. 634 (Ex. Ch. 1826).

92. Id. at 178-79, 148 Eng. Rep. at 635.

93. Compare the rule as to subpoeua of documents, note 79 supra. 
time. ${ }^{94}$ Because the party could not testify even if he were called as an adverse witness, it would have been very useful to be able to call his attorney. The attorney-chent privilege blocked that, at least so far as directly relevant revelations were concerned. And indeed the books suggest that this was a reason for the privilege-it prevented obtaining a party's testimony indirectly when it could not be adduced directly. ${ }^{95}$ But in equity proceedings, through the discovery process, could a party be made to answer questions and produce his memoranda to counsel, for those surely imclude facts within the party's knowledge? The answer was that indeed they must be produced, ${ }^{96}$ a rule renewed in Preston $v$. Carr. ${ }^{97}$

As of 1830, the attorney-client privilege in England stood im this relatively definite but very limited state. It then received a redefinition in rhetoric that greatly enlarged its potential scope. But this same rhetoric also submerged the boundaries of the privilege into confusion, of which there are still traces today. The author of this expansion was Lord Brougham, ${ }^{98} \mathrm{~m}$ the two cases of Bolton v. Corporation of Liverpool ${ }^{99}$ and Greenough v. Gaskell, ${ }^{100}$ both decided in 1833.

Bolton was a Chancery bill of discovery in aid of an action at law then pending. The action at law was by the corporation of Liverpool to recover from certain merehants dues and tolls under various more or less ancient privileges, riglits, and liberties elaimed by the city. The essential dispute appears to have concerned the validity of these privileges, rights, and kberties, and their interpretation as apphed to the

94. See The King v. Inhabitants of Woburn, 10 East 395, 103 Eng. Rep. 825 (K.B. 1808); Bull v. Loveland, 27 Mass. (10 Pick.) 9 (Mass. 1830); 2 J. WigMORE, supra note 8 , $\$ \$ 575$ et. seq.

95. See the argument in Annesley v. Anglesea, 17 How. St. Tr. 1139,1225 (1743).

96. This was the situation in Radcliff v. Fursman, 2 Brown 514, 1 Eug. Rep. 1101 (H.L. 1730). See also Richards v. Jackson, 18 Ves. Jun. 472, 34 Eng. Rep. 396 (Ch. 1812).

97. One obvious way to avoid this kind of disclosure was for the chent to communicate his recollection of the facts orally rather than in writing. The attorney could not be called, because of the privilege, and the client if deposed could recall as he might wish. This might confront the attorney with a situation where a client's testimony is at variance with an earher account given the attorney, which in turn raises a problem of revealing client perjury. See text accompanying note 25 supra. When the client has become a potential witness, and if he determines to tell a story different from what he has given his attorney, the attorney has to infringe either on his duty of confidentiality toward the client or his duty of candor toward the court.

98. Brougham, it may be recalled, had already made a considerable contribution to the legal definition of the lawyer's role. While at the bar he liad represented Queen Caroline in her disputation with George IV over their inarital differences and obligatious. To counter an effort by the King to divorce Caroline on the ground of adultery, Brougham as her counsel announced readiness to assert a defense, that of recrimination, which would raise questions of the legitimacy of royal succession. And in doing so he stated what remains the basic credo of loyalty to client: "Separating the duty of a patriot from that of an advocate, he must go on reckless of consequences, though it sliould be his unhappy fate to involve his country in confusion." 2 Trial of Queen Caroline 8 (1821). See also D. Mellinkoff, The Conscience of A LaWYer 188-89 (1973). A decade after this performance at the bar, Broughain found himself presiding in the Court of Chancery.

99. I Myl. \& K. 88, 39 Eng. Rep. 614 (Cl. 1833).

100. 1 Myl. \& K. 98, 39 Eng. Rep. 618 (Ch. 1833). 
merchants from whom the city was attempting to collect the exactions. Prior to bringing the action at law, the city submitted to counsel a number of statements of fact, accompamied by qucries, seekmg an opinion on these matters. The merchants as plamtiffs in equity sought discovery of these submissions, and the defendant city invoked the privilege. Greenough v. Gaskell was an action to cancel a note executed by the plaintiff on the ground that the note was procured by fraudulent concealments of the defendant Gaskell, who acted as solicitor for one Darwell. Plaintiff sought production from Gaskell of Darwell's financial papers and records, which were in Gaskell's possession. Gaskell claimed that he had made or received the papers and records as Darwell's "confidential solicitor."

Together, Bolton and Greenough encompass a broad range of coinnunications: from client to lawyer, and from lawyer to client; legal advice in a strict technical sense and business-financial assistance of the sort rendered by an office lawyer; communications between barrister and chent and between solicitor and chent; exchangcs in conteinplation of litigation and ones not occasioned by the specific prospect of imminent litigation; and communications as such and the transmission of tangible items, such as preexisting docunnents, from chent to lawyer.

Brougham held all of these matters immune from disclosure. To reach that result he had to narrow the scope of some cases, to construe others squintingly, and simply to ignore many more. In particular, he handled Annesley v. Anglesea in about the only way possible, that is by not citing it at all. ${ }^{101}$ As a demonstration of manipulating precedent, ${ }^{102}$ Brougham's perfornance is unsurpassed. As a resumé of existing law, it bore practically no resemblance to reality. But the opinions left no doubt as to where Brougham was going. Thus in Bolton he said:

It seems plain, that the course of justice inust stop if such a right [of discovery of submissions to counsel] exists. No man will dare to consult a professional adviser with a view to his defencc or to the enforcement of his rights. ${ }^{103}$

And in Greenough:

If the privilege were confined to communications connected with suits begun, or intended, or expected, or apprehended, no one could safely adopt such precautions as might eventually rendcr any proceedings successful, or all proceedimgs superflous. ${ }^{104}$

If these premises are taken as statement of the applicable principle, and not merely one of the competing considerations involved, then the privilege has few if any limits. For the terms of Broughan's premises

101. See text accompanying notes 68-77 supra.

102. See 1 Myl. \& K. at 105-114, 39 Eng. Rep. at 621-25.

103. Id. at 94, 39 Eng. Rep. at 617 .

104. Id. at 103, 39 Eng. Rep. at 621 . 
are not limited to matters either past or future, nor to consultations necessary to advice as distinct from ones incident to advice, nor to "legal" as distinct from business-financial matters. They do not distinguish lawful from unlawful purposes. They wholly disconnect the privilege from its point of origin - the fact that in court the chent could not speak for himself and therefore had to inform someone to speak for him. ${ }^{105}$

\section{Mediation of the Privilege}

Brougham's reformulation of the privilege represented a substantial departure from precedent, and was not fully accepted as an authoritative statement of the law in subsequent cases. ${ }^{106}$ His justification of the privilege has the great attractiveness of all one-sided propositions. But it ignores the dilemma: the definition of the privilege will express a value choice between protection of privacy and discovery of truth and the choice of either involves the acceptance of an evil-betrayal of confidence or suppression of truth.

The case of Flight $v$. Robinson ${ }^{107}$ reasserted the philosophy of disclosure from the earher decisions. That case involved a bill for discovery from the party of statements made to an attorney in connection with financial transactions that resulted in insolvency. The court observed the contradiction between the primciple of confidentiality upon which privilege is based and the principle of truth-disclosure that is the raison d'etre of an equitable bill of discovery:

The arguments [for the privilege] . . . have assumed, that concealment of the truth was, under the plausible names of protection or privilege, an object which it was particularly desirable to secure, forgetting ... that the principle upon which this Court has always acted, is to promote and compel the disclosure of the whole truth relevant to the matters in question. ${ }^{108}$

After examining the precedents, the Master of the Rolls concluded, "I am, therefore, not to order the Defendants to produce documents which are properly to be considered as confidential communications made between solicitor and client, and which took place, either in the progress of the suit, or with reference to the suit previously to its commencement." 109 This fornulation is obviously

105. See text accompanying note 65 supra.

106. See, e.g., Nias v. Northern \& Eastern Railway, 3 Myl. \& Craig 355, 40 Eng. Rep. 963 (Ch. 1838), in which the court took note of the fact that at least some of the earlier decisions were quite different in tenor from Brougham's opinions. That case lield that the privilege did not attach to communications put to an attorney for advice long im advance of what later developed into a lawsuit.

107. 8 Beav. 22, 50 Eng. Rep. 9 (Ch. 1844).

108. Id. at 35, 50 Eng. Rep. at 14.

109. Id. at 38, 50 Eng. Rep. at 15. 
narrower than Brougham's Greenough v. Gaskell, for it limits the privilege to communications concerning a pending suit or one immediately in prospect-the boundaries that had been suggested in the older decisions.

The court's discussion also reveals very clearly the difficulty arising from the relation between the rule of attorney-client privilege and the obligation of an attorney to avoid deception of a court by permitting submission of false or misleadimg evidence. In reaching its decision, the court adverted to the difference between the rules governing testimonial evidence in actions at law and those applicable in equity. ${ }^{110}$ "In this Court, the only case to be made out against the Defendant may rest within his own knowledge. The Plaintiff may know, or be able to prove nothing which justifies unore than a mere suspicion, and yet the Defendant must, on his oath, disclose the truth."111 And this in turn would pose a dilemma for the attorney if the client disclosed something other thian the truth. ${ }^{112}$

This dilemma seems to have become apparent only at this relatively late date-the mid-nineteentl century. ${ }^{113}$ It had to become worse when parties became competent as witnesses not only in equity but also at law. Two powerful premises then stood in unavoidable conflict: "the principle . . . to promote and compel the disclosure of the whole truth relevant to the niatters in question," 114 and that "the course of justice must stop if such a right to confidentiality exists." 115

Subsequent English cases struggled with this conflict, as we still do today. Their labors were the more difficult because the judges generally tried sonehow to reconcile the precedents instead of openly acknowledging their contradictions. Only two of those cases are addressed here. Both deal with the serious problems arising when it appears that the client is einbarked on a crime or fraud.

In The Queen v. Cox and Railton, ${ }^{116}$ the situation was, this: B and C as partners published a newspaper in which a hbelous statement about $P$ appeared. $P$ brought an action and recovered a substantial judgment.

110. See text accompanying notes 94-97 supra.

111. 8 Beav. at 35,50 Eng. Rep. at 14.

112. See note 97 supra.

113. In Charlton v. Coombes, $4 \mathrm{Giff} 377$ (Ch. 1863), it was held that by reason of privilege a solicitor could not be compelled to produce letters that would show his client had perpetrated a fraud on the court. The decision rests on the broad language of Greenough v. Gaskell, 1 Myl. \& K. 98, 39 Eng. Rep. 618 (Ch. 1833), and therefore does not take adequate account of the limitations on the privilege ignored in that decision. The decision also seens incompatible with Queen v. Cox and Railton, 14 Q.B.D. 153 (1884), considered in text accompanying notes 116-19 infra.

114. Flight v. Robimson, 8 Beav. 22, 35, 50 Eng. Rep. 9, 14 (Ch. 1844).

115. Bolton v. Corporation of Liverpool, 1 Myl. \& K. 88, 94, 39 Eng. Rep. 614, 617 (Cl. 1833).

116. 14 Q.B.D. 153 (1884). 
Four days after the judgment, $\mathrm{B}$ and $\mathrm{C}$ consulted their solicitor, who had prepared the original partnership deed, as to whether anything could be done to put the partnership property out of reach of the judgment. The solicitor advised them that only a sale to a bona fide purchaser would do that. They asked whether a sale from one of them to the other would suffice, and he rephed that it would not because of the partnership. In later proceedimgs to enforce the judgment, B and C introduced the partnership deed, cancelled as of a date before the judgment. A criminal prosecution followed. The solicitor was called to testify to the conversation in the consultation in order to show circumstantially that the cancellation occurred after the judgment, and that the transfer of the assets was therefore fraudulent.

The court denied apphication of the privilege. After an elaborate review of the cases, going back to Annesley v. Anglesea, the opimion concluded:

In order that the rule may apply there must be both professional confidence and professional employment, but if the client has a criminal object in view in his communications with his solicitor one of these elements must necessarily be absent. The client must either conspire with the solicitor or deceive him. If his criminal object is avowed, the client does not consult his advisor professionally, because it cannot be the solicitor's business to further any criminal object. If the chent does not avow his object he reposes no confidence, for the state of facts, which is the foundation of the supposed confidence, does not exist. The solicitor's advice is obtained by a fraud. ${ }^{117}$

The court was careful to distinguish between consultations for the purpose of receiving guidance to commit a proposed crime and communications "after the commission of the crime for the legitimate purpose of being defended." 118 The same analysis was later adopted for consultations in regard to a client's proposed civil fraud. ${ }^{119}$

\section{E. Privilege in the New World}

There appear to be no American cases on the attorney-chent privilege until the 1820's. ${ }^{120}$ In New England, the first reported case dealing

117. Id. at 168.

118. Id. at 175 .

119. In re Postlethwaite, 35 Ch. D. 177 (1887).

120. Wigmore's presentation of the absorption of the rule into American law is breathtaking. Having portrayed the development im England as an imexorable novement from Elizabethan beginning to Victorian triumph, suppressing both the Georgian confinement and the Victorian reservations, he then says: "In the United States this lengthy controversy seems never to have found echoes." $8 \mathrm{~J}$. WIGMORE, supra note 8 , at 563 . My research does not extend to unreported sources in the colonies and early years of the states, but it would be surprising to find in them a strong hospitality for the privilege. For example, 2 N.Y. REv. STAT. $§ 92$ (1836) provides for the priestpenitent privilege and $\S 93$ provides for a doctor-patient privilege, but there is no similar provision for the attorney-client relationship. At any rate, not only the "echoes" but the original sounds of 
with the problem is Dixon v. Parmelee. ${ }^{121}$ It recognized Annesley $v$. Anglesea as definitive authority in a long dictum expounding the confined view of the privilege found in Enghish doctrine at the time:

[T]his privilege, in all the cases which have fallen under my observation, has been strictly confined to the period in which the suit has been pending, and to the party of record, or in interest; and where the substance of the cominunication was such that it became necessary for the attorney to know it in order to manage the suit. . . . But this rule is not to be extended to all the subjects or conversations which a client may have with his attorney, nor to any period but that from his retainer to the termination of the suit. ...

Any matter of fact the knowledge of which the attorney had, other than from his client, the attorney is bound to disclose. . . . And where an attorney is retained generally, and a conversation is upon a subject which afterwards gives rise to a suit, the attorney is bound to disclose it, there being no suit in contemplation when the conversation was had. . . .122

The issue caine up again shortly thereafter im Massachusetts in two decisions ${ }^{123}$ by Chief Judge Shaw which can be charitably described as in tension with each other. Both involved attempts to prove through an attorney that a debtor asked him to draft a conveyance of property to another for the purpose of defrauding creditors. In the first case, the court sustained the privilege, holdmg that the privilege is not confined to "communications . . . in relation to the prosecution or defence of a suit at law, existing or contemplated," but also extends to "other cases, when a person has occasion to avail himself of the superior knowledge and skill of a professional man, in understanding his legal rights . . . ."124 The second case, however, held that the privilege did not exclude the attorney's testimony concerning the circuunstances in which he prepared the conveyance:

[W]e cannot perceive that the communications were made to the debtor] . . . with the purpose of instructing him in any cause, or engaging him in the conduct of any professional business, or of obtaming any legal advice or opinion. If the disclosure of his views and purposes, in the conveyance of the property proposed to be drawn, was not, as stated in sonie of the books, a mere gratis dictum, the only purpose seems to have been to satisfy [the attorney's] mind, and remove any scruple he might entertain . . . and to convince him . . . it was not attended with noral turpitude. It did satisfy him . . . . Here was no legal ad-

the controversy over the scope of the attorney-client privilege were imported into this country in the earliest reports, as indicated in the text accompanying notes 121-29 infra.

121. 2 Vt. 185 (1829).

122. Id. at $188-89$.

123. Foster v. Hall, 29 Mass. (12 Pick.) 89 (1831); Hatton v. Robinson, 31 Mass. (14 Pick.) 416 (1833).

124. Foster v. Hall, 29 Mass. (12 Pick.) 89, 97 (1831). 
vice asked, no opinion requested as to the effect and operation of such a conveyance in point of law, and none given . . . . [I]f there was a purpose . . . it was to satisfy [the attorney's] . . . mind, upon a point of fact, not for the information of his own in point of law . . . 125

Distinguishing these cases is not easy. It hardly seems relevant that in the first case a Massachusetts debtor was attempting to swindle creditors with the aid of a Massachusetts lawyer, while in the second case a Rhode Island debtor used a Rhode Island lawyer to swindle Massachusetts creditors. It inay well be relevant, however, that in the first case the testimony was excluded at trial on the basis of the privilege, while in the second it was admitted by the trial court and the denial of privilege was asserted as error on appeal. But the court's articulated basis for distinguishing the two cases surely inade the result turn on an irrelevancy. This was that the circumstantial facts given by the client in the second case were aimed at assuring the attorney that the transaction "was not attended by noral turpitude," whereas in the earlier case the corrupt purpose had been unabashedly revealed by the client. If that distinction were adopted, the privilege would not apply when the client is dislionest and tlie lawyer is innocent, ${ }^{126}$ but would apply when the two are in league to swindle. This in effect makes the attorney-client privilege a special privilege against self-implication for lawyers. ${ }^{127}$

The New York cases of the same period evidence a similar aunbivalence toward the privilege. In 1823 the privilege was affirned in unqualified terins by Chancellor Kent, wlio cited no authority and probably thouglit he needed none. ${ }^{128}$ Two decades later, Cliancellor Walworth was faced with the classic problem of a fraudulent sclieme, in Bank of Utica $v$. Mersereau, ${ }^{129}$ this time the procurement of a judgment to defeat the claims of prior creditors, and reluctantly concluded that the privilege applied:

125. Hatton v. Robinson, 31 Mass. (14 Pick.) 416, 423-24 (1883).

126. Either because he is duped, as in Hatton v. Robinson, 31 Mass. (14 Pick.) 416 (1833), or because, having been apprised of the client's fraudulent purpose as in Foster v. Hall, 29 Mass. (12 Pick.) 89 (1831), he declines to serve in carrying it out.

127. Massachusetts jurisprudence apparently lias never attempted to reconcile these cases. As often lrappens with contradictory precedents, they were happily cited together down through the years, see, e.g., Brooks v. Holden, 175 Mass. 137, 141, 55 N.E. 802, 804 (1900), until they inore or less disappeared through supersession.

128. Wilson v. Troup, 2 Cow. 195 (1823):

[The lawyer] was employed . . . to foreclose the inortgage, and lie says he believes that the business of conducting the foreclosure would not have been confined to him, if he had not been a lawyer. It was professional busimess, and in respect to that particular transaction, the parties appear to have stood in the relation of attorney and client, and the communications in the letters [of the chent], prior to the sale, were upon every reasonable ground, entitled to the protection of that relation, as confidential communications.

Id. at 205 .

129. 3 Barb. Ch. 528 (1848). 
The seal of professional confidence I believe has never been held to cover a communication made to an attorney to obtain professional advice or assistance as to the commission of a felony or other crime which was malum in se. . . . And. . . if the question had arisen for the first time in this case, I should have no hesitation in deciding that the communications . . . were not privileged; because they were made for the purpose of getting his professional assistance in the perpetration of a fraud upon their creditors. It is as contrary to the duty of an attorney, or a counsellor, to aid his chent, by professional services, in the perpetration of a fraud, or in the violation of any law of the state, as it is to aid him in the commission of a felony ... . The practice, however, appears to have been otherwise for more than a century and a half; and I do not feel authorized to adopt a new rule on the subject. ${ }^{130}$

On the other hand, three years later Judge Selden held the privilege did not protect testimony from an attorney offered to prove that his client was an undisclosed principal and as such liable on an obligation in favor of plaintiff. ${ }^{131}$ The court considered the privilege mapplicable wlien a lawyer is acting as a business agent for his client, which is perliaps a proper distmction to draw. In commenting on the privilege, the court relied strongly on Annesley v. Anglesea, and did not even cite Walworth's discussion in Bank of Utica $v$. Mersereau: ${ }^{132}$

[T]he rule is not founded upon any broad views of public policy, growing out of the inconveniences to society, of having confidential communications . . . liable to be disclosed, because this reasoning would apply with equal force to ... many cases which have never been held to be within the protection of the rule.

The doctrine has a narrower foundation . . . Anciently . . . parties litigant . . . prosecuted or defended their own causes. . . . Afterwards . . . it became indispensable to have a body of men trained to and skilled in the laws. . . and to have the busmess of courts transacted by these learned men. Suitors . . . were compelled to disclose to them the facts .... If the facts thus commumicated were liable to be extorted froin the attorney or counsel, suitors would hesitate to employ them, to the great inconvenience of the court. . . .

It follows from this reasoning, that originally no communications were protected except such as related to the management of some suit or judicial proceeding in court, then actually pending, or in the contemplation of the parties at the time; and if the numerous cases in which a wider scope has been given to the rule, should be held to have in some degree enlarged its application, this departure fron the true principle, ought to be confined within as narrow limits as possible. ${ }^{133}$

130. Id. at 598.

131. Rochester City Bank v. Suydam, Sage \& Co., 5 How. Pr. 254 (N.Y. Sup. Ct. 1851).

132. 3 Barb. Ch. 528 (1848).

133. 5 How. Pr. at 258-61. 
As one can see, "tradition," both English and American, thus clearly sustained a privilege confined to those communications that are related directly to pending or anticipated litigation.

\section{CONCLUSION}

The rule of confidentiahty is critical to the unodern lawyer's role, as advisor to clients probably even more than as advocate. It has always been recognized that the rule must have some limits, for at miniinum it is inadmissible that legal consultation be a cover for thuggery and theft. The difficult problein is where to draw the boundaries-how to define the kinds of secrets that a lawyer may not keep. This inquiry into the rule's origins provides little guidance in that task, for it shows that the problem has been difficult from the beginning. Better no light from history, however, than false light. 
